\title{
More Value from Fewer Resources \\ How to Expand Value Stream Mapping with ideas from Circular Economy
}

\begin{abstract}
Purpose:

The purpose of this paper is to discuss recent trends in the circular economy and investigate how value stream mapping (VSM) can be extended to more fully include some of the critical aspects of circular economy.
\end{abstract}

\section{Design/methodology/approach}

The findings are based on previous research that has explored the usage of VSM to include aspects of the environment and sustainability aspects. These ideas are then expanded to new ways to use VSM by mapping value of a product as it is; used, maintained, re used, remanufactured, recycled, incinerated or used for land fill. We test out this approach through application in the waste management sector to identify possibilities for improvement and new business opportunities in what now is considered waste.

\section{Findings}

This paper introduces an expanded version of VSM that refines the existing Lean tool-box for exploring value and mapping value in a circular economy.

\section{Originality/value}

Today, Value Stream Mapping (VSM) is a widespread method within Lean manufacturing that scrutinizes value creation within an organization or within a value chain. This paper describes how VSM can be refined to explore value streams in the afterlife of a product and explore waste as a resource utilization opportunity.

Keywords - Value Stream mapping, Material flow analysis, Lean, Supply chain, Life Cycle Analysis

\section{Introduction}

To accelerate change towards sustainable manufacturing and a circular economy, a number of steps need to be taken to increase efficiency in manufacturing and resource utilization. Increasing materials utilization requires enterprises to look at different ways to reduce, recycle, and reuse their raw and waste materials as well as extending the life cycle of their products.

Progress is being made in the sphere of industrial sustainable development. However, global challenges remain and they are significant (MacArthur, 2013) as global industrial systems are targeted to double output while using 50\% fewer resources, and generating only $20 \%$ of current $\mathrm{CO}^{2}$ emissions (Bocken et al., 2013). This paper investigates how companies and 
industrial systems and networks might use value stream mapping (VSM) as a tool to enhance sustainability and accelerate change towards an eco-friendly, circular economy.

Today, Value Stream Mapping (VSM) is a widespread method within Lean manufacturing that scrutinizes value creation within an organization, from start of production to finished goods. VSM can also be used to study value creation throughout an entire value chain. However, VSM in its conventional form does not explicitly take into account environmental and societal considerations or the new possibilities emerging from a circular economy. This paper describes how to change that by arguing that VSM can be refined to explore waste as a resource utilization opportunity.

When it comes to industrial operational processes, the concept "first things first" governs, and it means a rigorous focus on the success of the principle process that produces the main product or service. It is of paramount importance to have control of sales, manufacturing, logistics, delivery and so on, and use every opportunity to improve the efficiency of the main manufacturing process so as to maintain market share and to develop. Such focus may explain why successful and environmentally-aware organizations can still have much to improve in terms of supporting processes like their material utilization.

The purpose of this paper is to discuss recent trends in the circular economy and investigate how VSM can be extended to more fully include some of the critical aspects of circular economy. We test out this approach through application in the waste management sector to identify possibilities for improvement and new business opportunities in what now is considered waste.

\section{Introduction to VSM}

VSM has become one of the most popular and widespread development tools within the Lean community (Bicheno, 2015). It is a system level tool that maps material and information flows within an organization or throughout the whole value chain (ibid). These "streams" are mapped in order to understand the current conditions and also, maybe even more importantly, with the aim of finding a future state (Rother \& Shook, 2001). The future state can be farsighted, visionary, and hard to reach, or achievable after overcoming obstacles and conducting a series of improvements. The theory of VSM evolved quickly after it was first outlined as a series of tools by Hines \& Rich, (1997) and shortly after by Womack and Jones (1997). The latter vividly described the 319-day journey of a soft drink can and its flow from raw metal to finished product on a shelf in a store. However, the real mapping, or drawing of maps, started when Rother and Shook (1999) shared their pictures of current and future value streams. Since then their approach to VSM has been used in a semi-standardized way to guide organizations in their bigger picture planning and development of processes and supply chains.

The concept and usage of VSM has been expanded from the original internal company focus in a number of ways: towards 'Seeing the whole' value chain (Jones and Womack, 2002); 
and further to product development (McManus, 2005); to including environmental impact and energy consumption (Mason et al., 2008; Torres et al., 2009; Paju et al., 2010; Vinodh, S. et al., 2011; Brown et al., 2014; Faulkner \& Badurdeen, 2014; Vinodh, S. et al., 2016; Helleno et al., 2017 and Garza-Reyes et al 2018); and as a tool to include waste management (Kurdve, 2015). There have been three phases to the evolution of value stream mapping so far. The first was based on the concept of using various mapping tools to map or understand what happens in the value stream. The second, with the mapping tool from Rother \& Shook, and the third phase use extensions of the original idea. In this paper we refer to these extended Value stream maps as VSMx. The three phases are summarized in Table I below.

Table I. Evolution of Value stream mapping

\begin{tabular}{|l|l|l|}
\hline Value stream mapping & Value stream mapping, VSM & Value stream mapping, VSMx \\
\hline $\begin{array}{l}\text { Tools and methods that } \\
\text { evaluate and map the value } \\
\text { stream }\end{array}$ & VSM - learning to see & Extending the VSM method \\
\hline Hines \& Rich, (1997) & Rother and Shook (1999) & Various authors \\
\hline
\end{tabular}

\section{What does a value stream map look like?}

One of the overall goals and benefits of VSM is being able to visualize an operation effectively. The flow of material is drawn and shown using standardized symbols that show how value is added to the product step-by-step, as well as how and which information is supplied to each step (Rother \& Shook, 1999). The difference between a VSM map and a process map is sometimes hard to pinpoint, but one very distinctive difference is the timeline that is always present in a value stream map (ibid.). The presence of the timeline serves to put the value adding time in the perspective of the lead-time, see Figure 1.

Another distinctive feature of a value stream mapping is the data boxes, which are used to collect data needed from each process during mapping activities.

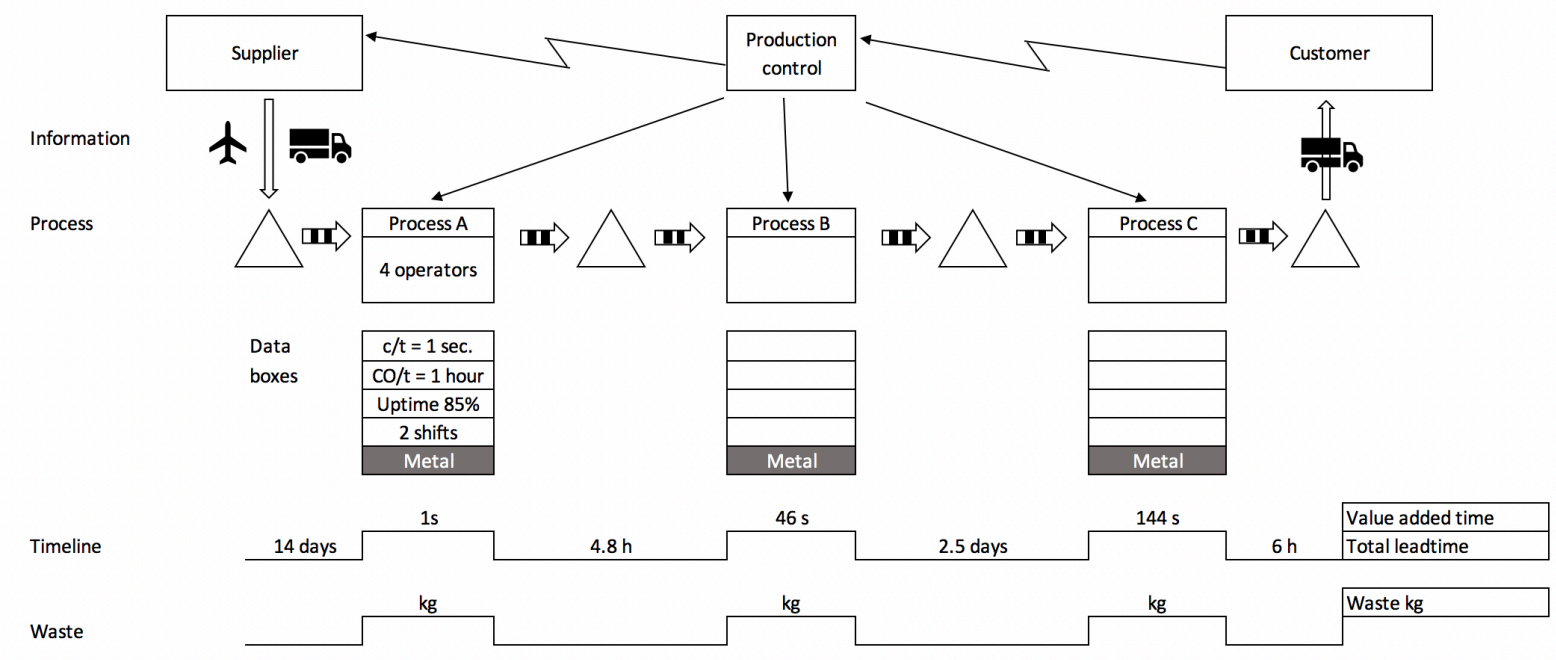

Figure 1. VSM with information and material flows and the timeline at the bottom with value adding time in the top segments and non-value adding time in lower segments. 
VSM is larger than a set of tools used to visualize the as-is state, it is also an improvement method in which the as-is state is first mapped, followed by a sketch of a to-be desired state, called the future state in VSM (Rother \& Shook, 1999). Once both the current and future states have been mapped, the third step in the VSM method is to create an action plan that will lead to the future state.

\section{Value definition within VSM}

Without a definition of value there can be no value stream mapping. However, the definition of value is not very precisely defined within the VSM literature. In Lean Thinking (Womack \& Jones 1992) value can only be defined by the ultimate customer, but manufacturing companies build value into their products. Within Lean, identifying the value stream and defining what value creation is and what it is not is difficult (ibid.). Nonetheless, the questions asked while analyzing value creation will eventually lead to an improved value stream. When value is understood and defined, the process of improving the value stream can start. Within Lean this can be done by waste removal, where waste, or Muda, is all non valueadding activities (ibid.).

\section{Limits of traditional VSM}

For many years, organizations and enterprises have focused on processes and development of value chains (Porter, 2011). The aim of this has been to improve efficiency and to become more competitive. In this work, VSM is one tool that can help organizations to identify and reduce waste and improve creation of value. This is done by seeing the entire process or value chain from the perspective of a system. The reduction of waste can occur in many forms, not only the classical seven wastes as described by Liker, (2005). However, VSMs shortcoming is that, to the best of our knowledge, it has not thus far systematically included the principles of a circular economy.

\section{Expanding traditional VSM - Literature study from 2008-2018}

A literature study was conducted with the aim of finding papers related to VSM and extended VSM that also considered aspects of the environment, sustainability, and the circular economy. The Scopus database was used for this, and the search words were "value stream mapping" AND "Sustainability", The search was limited to publications from 2008 onwards, which resulted in 50 hits. The first screening of these results included reading and evaluating the abstracts to assess their relevance to the field of interest. Fourteen publications passed this screening and were studied in more detail. The publications were categorized according to four identified subcategories, their type of study, main objective, kind of environmental parameter(s), and system limit. The main contents of the publications are summarized in Table II. The studied papers can be divided into four distinct subcategories. First publications that includes some aspect of environmental mapping, secondly a category which integrates social sustainability aspects into VSM, thirdly VSM which incorporates logistics and lastly mapping of shop-floor mapping of waste material. The overall number of screened and analyzed publications are relatively small. 
Table II Summary of value stream mapping literature with extended scope

\begin{tabular}{|c|c|c|c|}
\hline Subcategory & Main objective & $\begin{array}{l}\text { Example of mapped } \\
\text { indicator }\end{array}$ & References \\
\hline $\begin{array}{l}\text { Environmental VSM } \\
\text { Also known as: } \\
\text { Sustainable value } \\
\text { stream mapping, (Sus- } \\
\text { VSM), E-VSM, e- } \\
\text { VSM, VSM + LCA, } \\
\text { Lean and green }\end{array}$ & $\begin{array}{l}\text { Integrating } \\
\text { environmental } \\
\text { aspects into VSM. } \\
\text { Uses the data box in } \\
\text { VSM to collect } \\
\text { environmental data }\end{array}$ & $\begin{array}{l}\text { Energy, material } \\
\text { consumption, process } \\
\text { water, waste-water, } \\
\text { emissions }\end{array}$ & $\begin{array}{l}\text { Mason et al. (2008), } \\
\text { Torres et al. ( 2009), } \\
\text { Paju et al (2010), } \\
\text { Vinodh, S. et al. (2011), } \\
\text { Brown et al. (2014), } \\
\text { Faulkner \& Badurdeen } \\
(2014), \text { Kurdve et al. } \\
(2015), \text { Vinodh, S. et al. } \\
(2016), \text { Helleno et al. } \\
(2017), \text { Garza-Reyes et } \\
\text { al (2018) }\end{array}$ \\
\hline $\begin{array}{l}\text { Sustainable value } \\
\text { stream mapping } \\
\text { Also known as: Social } \\
\text { sustainable value } \\
\text { stream mapping, (sus- } \\
\text { VSM) }\end{array}$ & $\begin{array}{l}\text { Integrating social } \\
\text { sustainability aspects } \\
\text { into VSM. Uses the } \\
\text { data box in VSM to } \\
\text { collect sustainability } \\
\text { data }\end{array}$ & $\begin{array}{l}\text { Ergonomics, work } \\
\text { hazards, work risk } \\
\text { mapping }\end{array}$ & $\begin{array}{l}\text { Brown et al. (2014), } \\
\text { Faulkner \& Badurdeen } \\
\text { (2014), Vinodh, S. et al. } \\
\text { (2016), Helleno et al. } \\
(2017)\end{array}$ \\
\hline Logistics VSM & $\begin{array}{l}\text { Integrating logistics } \\
\text { aspects into VSM. } \\
\text { Supply chain } \\
\text { mapping }\end{array}$ & $\begin{array}{l}\mathrm{CO}^{2} \text { emissions, } \\
\text { logistics planning, on- } \\
\text { time delivery, } \\
\text { transportation waste }\end{array}$ & $\begin{array}{l}\text { Mason et al. (2008), } \\
\text { Suarez-Barraza et al. } \\
(2016) \text {, Garza-Reyes et } \\
\text { al (2018) }\end{array}$ \\
\hline $\begin{array}{l}\text { Waste flow mapping } \\
\text { (WFM) }\end{array}$ & $\begin{array}{l}\text { Integrating waste } \\
\text { management into } \\
\text { VSM }\end{array}$ & $\begin{array}{l}\text { Waste in the following } \\
\text { categories: Metals, } \\
\text { combustible material, } \\
\text { inert material, fluid } \\
\text { waste, other hazardous } \\
\text { waste }\end{array}$ & Kurdve et al. (2015) \\
\hline
\end{tabular}

\section{A model for expanding traditional VSM}

While some literature does appear to exist linking VSM to the circular economy, the concept of circularity as it is used within a circular economy has not yet found its way to practitioners that use lean tools such as VSM. We believe, and hope, that by including the thought models and thinking used in a circular economy, we will be able to extend the VSM concept even further. What would happen if we were able to include reusing and recycling at a material, component, and product level within manufacturing? What would happen if we included ideas like cradle-to-cradle (MacArthur, 2013), and in that context started thinking about what value means for customers when the traditional linear thought patterns of take-make-dispose are replaced? 


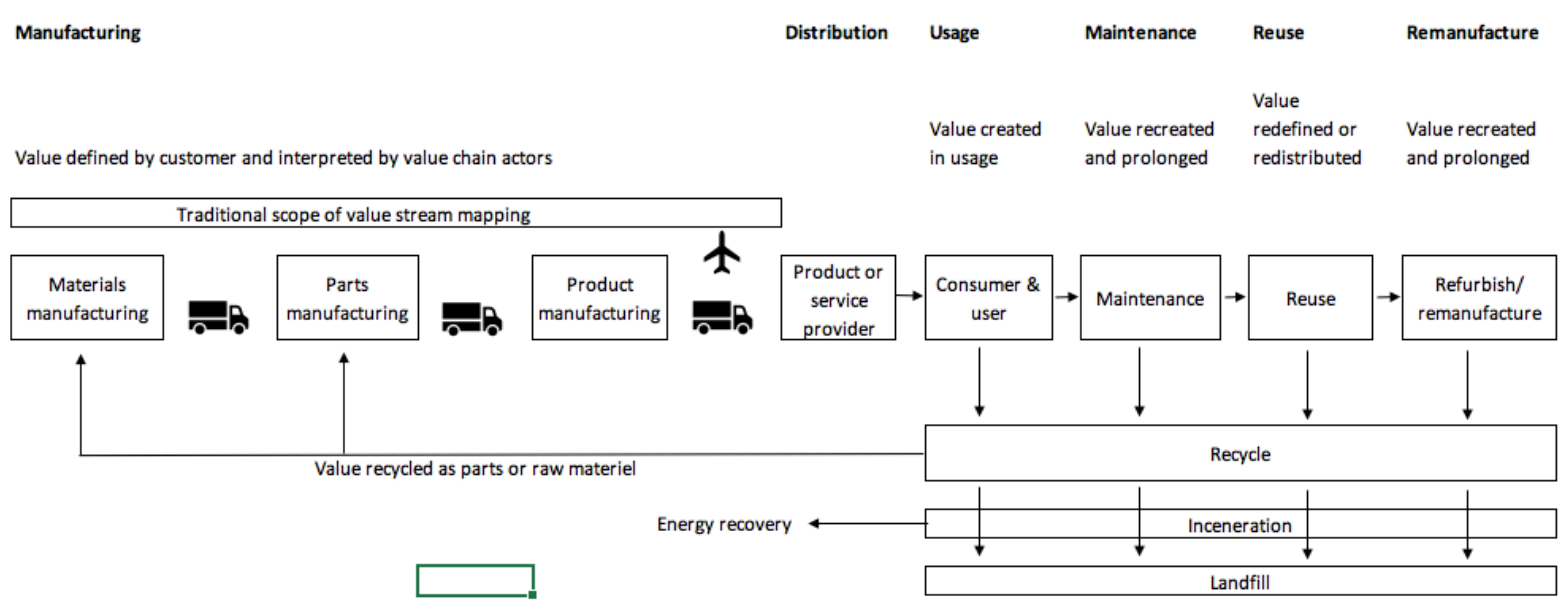

Figure 2. Extending value stream mapping into the overall scheme of a circular economy. Two parts of the value stream can be seen, first the value creation flow from raw material to finished product at a service provider and secondly, the value usage flow from the user's first usage to end-of-life of product and value destruction, recycling, and energy recovery. Developed from McArthur (2013)

\section{A circular economy}

Using global resources in an environmentally sustainable way has developed from first being an idea and theory, and the concept has evolved from ecological economics, environmental economics and industrial ecology (Ghisellini et al, 2016). The objective is to identify sustainable business models that can move us from usage of materials to circulation of material in closed loops (Naustdalslid, 2014; Ghisellini et al, 2016).

The concept of circular economy is covered in a review article by Ghisellini et al (2016). Early development includes definition and modeling work, as well as identification of three categories of implementation: micro, meso and macro level. The micro level refers to a single company or the consumer. In this category we find the formation of the fields of cleaner production, green consumption, and green public procurement, as well as product recycling, product reuse, scavenging, and decomposing of products. The middle level, or the meso level, (ibid.) includes eco-industrial parks and systems. In these systems, industries and companies co-exist in symbiosis. This category also covers the concept of waste trade markets. On the macro level, regional eco-industrial cooperation is expanded to regions or cities. This is urban symbiosis. Collaborative consumption and zero-waste programs, and municipal solid waste management systems are also found at this level. All implementation categories and the different implementation levels are found in Table III below.

Table III. Classification of subjects and categories of implementation within a circular economy. Adopted from Ghisellini et al, 2016. 


\begin{tabular}{|l|l|l|}
\hline $\begin{array}{l}\text { Implementation at micro } \\
\text { level (single company or } \\
\text { consumer) }\end{array}$ & $\begin{array}{l}\text { Implementation at meso } \\
\text { level (eco-industrial parks) }\end{array}$ & $\begin{array}{l}\text { Implementation at macro } \\
\text { level (city, region, nation) }\end{array}$ \\
\hline Cleaner production & $\begin{array}{l}\text { Eco-industrial systems and } \\
\text { symbiosis }\end{array}$ & $\begin{array}{l}\text { Regional eco-industrial } \\
\text { networks and production, } \\
\text { eco-cities, urban symbiosis }\end{array}$ \\
\hline $\begin{array}{l}\text { Green consumption and } \\
\text { green public procurement }\end{array}$ & Waste trade markets & Collaborative consumption \\
\hline $\begin{array}{l}\text { Product recycling and reuse. } \\
\text { Scavengers and } \\
\text { decomposers }\end{array}$ & & $\begin{array}{l}\text { Zero-waste programs, } \\
\text { innovative solid waste } \\
\text { management systems }\end{array}$ \\
\hline
\end{tabular}

The circular economy is currently being encouraged in different ways. In China, for example, it is used as part of the scientific development and economic strategy formulated by the 16th Party Congress in 2002 (Yuan et al, 2006; Naustdalslid, 2014). One of the goals of this strategy is harmonious development of the economy, society, and humanity by advocating balanced and sustainable development. With this policy-driven approach China as a country is trying to promote innovation and development to balance the environmental and social problems caused by its rapid and continuous economic growth (Ghisellini et al, 2016; Yuan et al, 2006). In other countries a circular economy is seen as a tool for policy-driven initiatives that aim to control market conditions for consumers and companies. Initiatives are simultaneously being driven by environmental organizations and civil society calling for a greener and cleaner world and actively demanding policy and legislation that enhances the green transformation (Naustdalslid, 2011).

One way to describe the manifestation of a circular economy is using the $3 \mathrm{R}$ model (Naustdalslid, 2014), which includes these principles:

- Reduction: The amount of material and other resources is reduced without affecting performance of the product.

- Reusing: Describes how the active usage and life-time of the product can be prolonged, or the product used for another purpose than what was initially intended.

- Recycling: The full circle recycling of material resources into usable recycled raw material.

The first principle, reduction, is very well established within manufacturing and is one of the points of departure for the scientific work of Taylor (2004). However the second and third principles, reusing and recycling, have so far not been seen by manufacturing companies as a main objective for them. The market and business of reusing has mostly existed between individuals. The fact that a longer life of a manufactured product affects its second-hand value is likely to be a consideration for both consumers and manufacturers. 


\section{Life cycle assessment}

The model that is currently most commonly used for quantifying the environmental impact of a product or system throughout its life cycle is the science-based assessment method referred to as Life cycle assessment (LCA) (Winkler \& Bilitewski, 2007). LCA provides a holistic view on the environmental performance of products, which has made it a critical tool for environmental policy decisions in public government and the manufacturing industry. As a holistic model, LCA is based on models that need extensive data collection and analysis to yield a result. This can become a complex process and consequently, LCA is mainly carried by scientists.

\section{Results and Findings}

\section{Waste as a resource}

To test how a VSM may be expanded with aspects of a circular economy, we studied two cases in the waste management sector. Could value be identified in what is currently considered waste?

\section{Case one - Energy recovery, the EU directive, and waste hierarchy}

Energy recovery is one part of the waste hierarchy, according to the EU's prioritization scheme in its Waste Directive 2008/98/ EC for the treatment of waste from an environmental point of view. The waste hierarchy lists waste prevention as the most desirable priority, ahead of preparation for reuse, recycling, other recycling (including energy recycling), and disposal (landfill or non-energy reclamation).

In 2015, 5.8 million tons of waste went to energy recovery at Swedish facilities (Source 2008/98 / EC). The UK and Ireland have introduced landfill taxes that have gradually increased and Norway has introduced a ban on the disposal of biodegradable waste. Swedish waste incineration plants offer competitive reception fees for this waste as district heating networks allow efficient use of the energy in the waste. Additionally, the high Swedish taxes on fossil fuels means that relatively expensive biofuels will become the main alternative for district heating production. The main waste streams exported from Ireland, Norway, and the UK are rejected from MRF facilities (Materials Recovery Facilities), MBT facilities (Mechanical Biological Treatment), and household and business waste that has undergone a varying degree of source sorting and/or post-sorting.

This indicates that there is potential for more sorting of waste to recycling from both MBT and MRF plants and through other sorting. There are two main reasons that explain why this is not currently done: firstly the value of material being sorted does not compensate for the additional costs that an extended sorting entails, and secondly, for some material fractions there is no market.

\section{Case two - Interview with a representative from the recycling industry}


An interview was carried out with a representative from a waste disposal company Lundstam's, (Marktin, 2018) to learn about their line of business and how it is connected to a circular economy. The company is a regional enterprise in Sweden that works with recycling of waste from companies, producer-collected materials, household waste, and so on. The business model of the company is to collect, sort, and resell or dispose of material fractions. They handle and sort about 50 different fractions of material varying from paper, fiber, and wood to plastics and metal, which are then sold for reuse, disposed, or used for energy recovery within Sweden and the EU.

Economic incentives exist that encourage Lundstam's customers to choose more circular solutions for managing their waste. The most costly option for them is to avoid sorting and having a plan for their waste. All improvements that Lundstam customers can find for the management of waste are directly profitable, and the higher up the recycling hierarchy, the more value the recycled material will have. In other words, managing waste means reducing costs, see Figure 3. Handling waste efficiently, in such a way that enables companies to also purchase materials that are easily recyclable for their business, can result in lower costs. As a comparison, in Sweden the cost for disposal of waste that can be burned is EUR 50-60 per $1000 \mathrm{~kg}$ (Marktin, 2018).

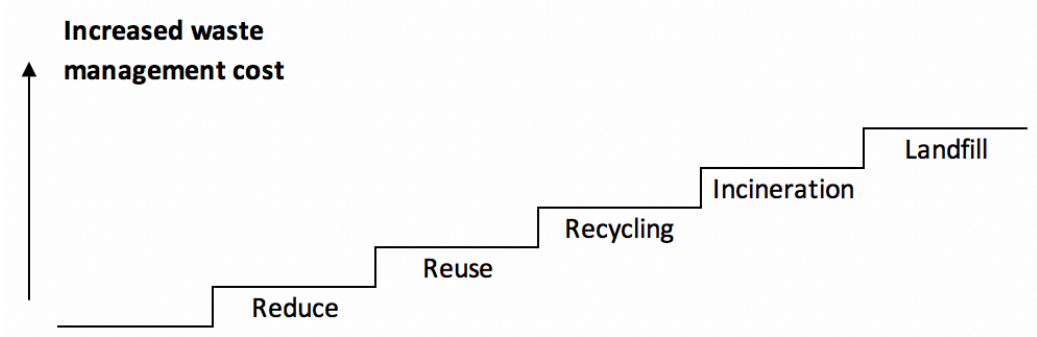

Figure 3.Waste disposal staircase as described by Marktin (2018). The cost difference between recycling more waste rather than sending waste for further treatment, incineration or disposal, may affect how waste is treated. The cost of disposal of waste decreases when Lundstam's customers move down the waste disposal stair case. This figure indicates that the highest cost for waste disposal is landfill, however this is not true for inert and organic materials suitable for landfill (ibid.).

The recycled secondary material also needs to be of a sufficiently high quality to compete with virgin raw material. The level of profitability from sorting more fractions of material for recycling is dependent on the composition of the waste, which in turn depends on both the extent to which the waste has been sorted and the available collection systems. If the potentially recyclable material is contaminated with other waste, it is harder and more expensive to sort it for recycling than if the waste has been sorted from the beginning with the objective of recycling material (ibid.).

This might indicate that applying VSM to the waste management system could identify value opportunities and reveal hidden value by identifying value. 


\section{Consequences of VSM application in a circular economy scenario}

So how might we proceed with including the thought models and thinking used in a circular economy to expand the VSM concept even further? Where might the additional value be? We have modeled the consequences from several different perspectives.

\section{Impact on consumer usage}

In the first period of usage we would start by mapping value-adding time, in other words, when the product is used. The total lead-time would be the time until the product is not considered usable any more. The product is then considered to be at the end of its life. In this phase we can increase the value-added time with respect to the total lead-time by either using the product more or shortening its lifetime. If we don't use the product we will be in a valuemissed regime where under-utilization consumes assets and material. Shortening a product's lifetime is instinctively unfamiliar, but if the product can be $100 \%$ recycled in an energyefficient way, fast usage and fast material recirculation may be desirable.

However, the choices made by the general public constitute a competing behavior in this regime. For example, in the UK the number of garments purchased increased by $35 \%$ between 2000 - 2005 (Allwood et al., 2011) and the average utilization of cars (utilization of car seats) was as low as $1.6 \%$ (ibid.). If the cost of a new pair of trousers or the cost of owning a car is low many people might select this option.

\section{Impact on consumer usage/maintenance}

In this phase, the ability to maintain the product in a simple, cheap, and environmentally sound way is of value for the customer. Not all products can be maintained though; one example would be disposable products.

\section{Impact on reuse of value or redistribution of value}

Here value-adding time can be increased if the product has a long lifetime and if the product has a market value in the redistributed form.

\section{Impact on refurbishment or re-manufacturing of value}

The objective here is to prolong value by refurbishing or remanufacturing the original value proposal of the product. This can include inspection, cleaning, disassembly, storage, repair, reassembly and testing, according to Allwood (2011). The outcome from using VSM in this value phase is connected to how efficiently value can be restored and brought back into usage. Disassembly followed by long time of storage is not effective in a VSM context.

\section{Impact on recycling of value}

The ability to recycle will increasingly receive more attention. The alternatives to recycling, incineration and landfill, are worse in terms of environmental impact. All products must be considered as recyclable, but the efficiency of the recycling is dependent upon design and choice of material. Part of the responsibility for making efficiently-recyclable products falls 
on the manufacturer who can alter designs and choose to build the product from virgin or recycled materials.

The customer will also need to accept some responsibility since the cost of making recyclable products, that can also be efficiently recycled, may be higher compared to products with the same function but with a lower degree of efficient recyclability. This gap would be interesting to investigate further. The gap is also an opportunity for policy makers. For instance, if the alternative cost for landfill or incineration is increased through taxation, manufacturers will rapidly seek new ways to improve recycling.

Other required behavioral changes would arise if the sharing economy and product leasing trends increased even further. For example, in Rome, car-pooling is very popular and has been promoted by the city council through initiatives such as favorable parking facilities for car-poolers. A measurement taken of car-pooling organizations showed that car-pooling cars are used on average as often as 3.7 times per day (Mugion et al., 2018). This indicates that through the scheme, cars and space are being used more per person than before.

With manufacturers switching from being product suppliers to service providers their interest in the product's aftermarket life increases. Indeed, the aftermarket value becomes equally as important as manufacturing, see Table IV - Ideal final results for the stakeholders. Please note that the ideal final results are to be seen as indicative of typical behaviors of the stakeholders.

Table IV. Ideal final results for different stakeholders

\begin{tabular}{|l|l|l|l|}
\hline Value phase aspects & \multicolumn{2}{|l|}{ Ideal final result } \\
\cline { 2 - 4 } & Customer/User & $\begin{array}{l}\text { Product supplier and } \\
\text { manufacturer }\end{array}$ & $\begin{array}{l}\text { Service provider and } \\
\text { manufacturer }\end{array}$ \\
\hline Product life-time & $\begin{array}{l}\text { Long or until } \\
\text { end of } \\
\text { technology life- } \\
\text { time }\end{array}$ & Until end of warranty & Long \\
\hline
\end{tabular}

\section{Conclusions and Discussion}

\section{Extending value stream mapping}

Using life-cycle analysis results in a total environmental impact of a product, from cradle to grave. However, the dynamic aspects of the product lifetime and the value a product can achieve during its lifetime are not described within LCA in any great detail. The story is different with VSM, which looks at increasing the proportion of value-adding time in relation to total lead-time. This logic enables us to increase value-add by compressing the product life-time or introducing sharing economies where the usage of products is increased. 
We can speculate as to how the environmental challenges can be addressed, and how change can be accelerated. This can be done through legislation and policy, through public choice and debate, and through a reinvented capitalism (Porter, 2011). This new capitalism is made possible by company success and self-interest in philanthropy.

Not all profit is equal. Profits involving a social purpose represent a higher form of capitalism, one that creates a positive cycle of company and community prosperity. (Porter, 2011, p 15)

We should keep in mind though that not all capitalists are philanthropic but they all react to economic incentives. In Sweden today, those incentives are stimulating material recycling of waste. From a market perspective, it can be theoretically argued that the more expensive it is to deposit or incinerate waste, the greater the economic incentive for switching to recycling as the most economically advantageous alternative. But just because there is an economic incentive that would prevent waste from occurring, there may be other reasons why this is not happening. In an article that studies mechanisms that prevent value co-creation in waste management industry Svingstedt and Covellec (2016) identify lock-in mechanisms that can explain slow or non-existent development of material recycling services. An example of lockins from Svingstedt et al (2016) is a transactional business model there the waste management service provider (or the incineration plant) depends upon waste volumes for their operations.

\section{Final thougths}

Goods produced from materials are essential to our way of living. From materials we build goods such as cars and washing machines, and the goods provide parts and components that become public transport and hospitals. These are all items and necessities that our societies are not willing to give up. Since the industrial revolution, manufacturing and consumption of raw materials have followed a linear route. This route has been: take, make, and dispose. This way of using materials is not sustainable, however. Today we know that the linear usage of material cannot go on forever. We also know that recycling material can reduce the need for virgin raw material. In some cases, recycling materials can be more cost-effective compared to using virgin raw material. This is certainly true for many metals like i.e. aluminium.

With this new knowledge, and the need for circular material flows, companies need effective, easy-to-use tools to help analyze and make decisions on how to transform their businesses in the direction of a circular economy. In this paper we have analyzed and tried to argue that VSM may be such a tool. The VSM method is well known in industry, it has been proven to reduce waste and reduce materials consumption, and produce products in a more efficient way. We propose that the same method can be used to "learn how to see" the value and the value stream of a product beyond its point of delivery to the customer. The value of the product is used, maintained, given new meaning, remanufactured and finally recycled. By looking at the value stream in this way we close the loop, and construct a circular value stream. 
The results from the analysis of using VSM in the back-end of the value stream are not novel in the sense that new insights have been found; indeed earlier findings have shown the same results. This is good news since the journey towards a circular economy cannot be made in one giant leap. This incremental journey will most likely be undertaken through a large number of baby steps. But how do we know which steps to begin with? One answer could be to analyze what the customer value is, and improve the value stream using VSM, and in the analysis of what is value we can also include the next and future generations of customers.

\section{Acknowledgments}

This study was carried out in the program Interreg Sweden-Norway financed by EU funds and Norwegian IR funds. The program's overall aim and objective is, through cross-border cooperation, to create the best conditions for an economically strong region with an attractive living environment. The particular project in which this study was conducted is called SMICE which aims at creating a long-term sustainable Jämtland, Härjedalen and Trøndelag.

\section{References}

Allwood, J. M., Ashby, M. F., Gutowski, T. G., \& Worrell, E. (2011). Material efficiency: A white paper. Resources, Conservation and Recycling, 55(3), 362-381.

Bocken, N., Short, S., Rana, P., \& Evans, S. (2013). A value mapping tool for sustainable business modelling. Corporate Governance, 13(5), 482-497.

Brown, A., Amundson, J., \& Badurdeen, F. (2014). Sustainable value stream mapping (SusVSM) in different manufacturing system configurations: application case studies. Journal of Cleaner Production, 85, 164-179.

Cleary, J. (2009). Life cycle assessments of municipal solid waste management systems: A comparative analysis of selected peer-reviewed literature. Environment international, 35(8), 1256-1266.

EC-European Commission. (2008). Directive 2008/98/EC of the European Parliament and of the Council of 19 November 2008 on waste. Official Journal of the European Union $L, 312(13), 22-11$.

Faulkner, W., \& Badurdeen, F. (2014). Sustainable Value Stream Mapping (Sus-VSM): methodology to visualize and assess manufacturing sustainability performance. Journal of cleaner production, $85,8-18$.

Garza-Reyes, J.A., Torres Romero, J., Govindan, K., Cherrafi, A.,Ramanathan, U., A PDCAbased approach to Environmental Value Stream Mapping (E-VSM), 2018 Journal of Cleaner Production, 180, pp. 335-348 
Ghisellini, P., Cialani, C., \& Ulgiati, S. (2016). A review on circular economy: the expected transition to a balanced interplay of environmental and economic systems. Journal of Cleaner Production, 114, 11-32.

Helleno, A. L., de Moraes, A. J. I., \& Simon, A. T. (2017). Integrating sustainability indicators and Lean Manufacturing to assess manufacturing processes: Application case studies in Brazilian industry. Journal of cleaner production, 153, 405-416.

Hines, P., \& Rich, N. (1997). The seven value stream mapping tools. International journal of operations \& production management, 17(1), 46-64.

Jones, D., \& Womack, J. (2002). Seeing the whole. Lean Enterprise Institute, Brookline.

Kurdve, M., Shahbazi, S., Wendin, M., Bengtsson, C., \& Wiktorsson, M. (2015). Waste flow mapping to improve sustainability of waste management: a case study approach. Journal of Cleaner Production, 98, 304-315.

Liker, J. K. (2005). The toyota way. Esensi.

Mason, R., Nieuwenhuis, P., \& Simons, D. (2008). Lean and green supply chain mapping: adapting a lean management tool to the needs of industrial ecology. Progress in Industrial Ecology, An International Journal, 5(4), 302-324.

Mattias Marktin, (2018). Personal communication.

MacArthur, E. (2013). Towards the circular economy. Journal of Industrial Ecology, 23-44.

McManus, H. L. (2005). Product development value stream mapping (PDVSM) manual release 1.0.

Mugion, R. G., Toni, M., Di Pietro, L., Pasca M. G., Renzi, M. F. (2018), Understanding the drivers of car sharing usage: The role of service quality. 21st QMOD conference on quality and service science ICQSS, 22-24 August 2018, Cardiff University, Wales, UK.

Naustdalslid, J. (2011). Climate change-the challenge of translating scientific knowledge into action. international Journal of sustainable Development \& World ecology, 18(3), 243-252.

Naustdalslid, J. (2014). Circular economy in China-the environmental dimension of the harmonious society. International Journal of Sustainable Development \& World Ecology, 21(4), 303-313.

Paju, M., Heilala, J., Hentula, M., Heikkilä, A., Johansson, B., Leong, S., \& Lyons, K. (2010, December). Framework and indicatßors for a sustainable manufacturing mapping methodology. In Proceedings of the Winter Simulation Conference (pp. 3411-3422). Winter 
Simulation Conference.

Porter, M. E. (2011). Competitive advantage of nations: creating and sustaining superior performance (Vol. 2). Simon and Schuster.

Porter, M. E., \& Kramer, M. R. (2019). Creating shared value. In Managing Sustainable Business (pp. 327-350). Springer, Dordrecht.

Rother, M., \& Shook, J. (1999). Learning to see. Lean Enterprise Institute, Cambridge, MA.

Serrano Lasa, I., Ochoa Laburu, C., \& de Castro Vila, R. (2008). An evaluation of the value stream mapping tool. Business process management journal, 14(1), 39-52.

Simons, D., \& Mason, R. (2003). Lean and green:'doing more with less'. International Commerce Review: ECR Journal, 3(1), 84.

Suarez-Barraza, M. F., Miguel-Davila, J. Á., \& Vasquez-García, C. F. (2016). Supply chain value stream mapping: a new tool of operation management. International Journal of Quality \& Reliability Management, 33(4), 518-534.

Svingstedt, A., \& Corvellec, H. (2018). When lock-ins impede value co-creation in service. International Journal of Quality and Service Sciences, 10(1), 2-15.

Taylor, F. W. (2004). Scientific management. Routledge.

Torres Jr, A. S., \& Gati, A. M. (2009, August). Environmental value stream mapping (EVSM) as sustainability management tool. In Management of Engineering \& Technology, 2009. PICMET 2009. Portland International Conference on (pp. 1689-1698). IEEE.

Vinodh, S., Arvind, K. R., \& Somanaathan, M. (2011). Tools and techniques for enabling sustainability through lean initiatives. Clean Technologies and Environmental Policy, 13(3), 469-479.

Vinodh, S., Ruben, R. B., \& Asokan, P. (2016). Life cycle assessment integrated value stream mapping framework to ensure sustainable manufacturing: a case study. Clean Technologies and Environmental Policy, 18(1), 279-295.

Winkler, J., \& Bilitewski, B. (2007). Comparative evaluation of life cycle assessment models for solid waste management. Waste management, 27(8), 1021-1031.

Womack, J. P., \& Jones, D. T. (1997). Lean thinking - banish waste and create wealth in your corporation. Journal of the Operational Research Society, 48(11), 1148-1148.

Yuan, Z., Bi, J., \& Moriguichi, Y. (2006). The circular economy: A new development 
strategy in China. Journal of Industrial Ecology, 10(1-2), 4-8. 